Instructions for authors, subscriptions and further details:

http://rimcis.hipatiapress.com

\title{
Theorizing Beta Thalassemia Major: An Overview of Health Sociology
}

Muhammad Abo ul Hassan Rashid ${ }^{1,2}$, Saif-Ur-Rehman Saif Abbasi $^{2}$

1) Shaheed Zulfikar Ali Bhutto Institute of Science and Technology, Pakistan

2) International Islamic University, Pakistan

Date of publication: March $30^{\text {th }}, 2020$

Edition period: March 2020 - July 2020

To cite and link this article: Rashid, M. A. H., \& Abbasi, S. S. (2020).

Theorizing Beta Thalassemia Major: An Overview of Health Sociology.

International and Multidisciplinary Journal of Social Sciences, 9(1), 51-75.

http://doi.org/10.17583/rimcis.2020.5113

\section{PLEASE SCROLL DOWN FOR ARTICLE}

The terms and conditions of use are related to the Open Journal System and to Creative Commons Attribution License (CC-BY). 
Sciences Vol. 9 No.1 March 2020 pp. 51-75

\section{Theorizing Beta Thalassemia Major: An Overview of Health Sociology}

Muhammad Abo ul Hassan

Rashid

Shaheed Zulfikar Ali Bhutto

Institute of Science and

Technology
Saif-Ur-Rehman Saif Abbasi

International Islamic University

\section{Abstract}

This research focuses on specific models of health and illness, explored by many researchers across the world. The sequential variations and critic of each model is summed up by researcher and the relevant theoretical orientations of beta thalassemia major have been tried to integrate. Beta thalassemia major is a common genetic disorder, due to abnormalities in human globin (alpha or beta). The highest prevalence rate of disease has been seen in Saudi Arabia, Jordon, India, Bangladesh and Pakistan, due to repeated cousin marriages, strong beliefs of cultural and traditional practices and lack of knowledge for the prevention and management of beta thalassemia major. The focus of epidemiologists remained on genetic causes and ignored the social, cultural, religious and psychological factors which preponderate over biological aspects of health. The academician and health experts lacked to focus the theoretical orientations of beta thalassemia major, this paper elucidates the models of health and illness and provides and logical theoretical itinerary for beta thalassemia major.

Keywords: Beta Thalassemia Major, Sociology, Health, Illness, Bio-psychosocial 
Sciences Vol. 9 No.1 March 2019 pp. 51-75

\section{Teorizando la Beta Talasemia Mayor: Una Visión General de la Sociología de la Salud}

Muhammad Abo ul Hassan

Rashid

Shaheed Zulfikar Ali Bhutto

Institute of Science and

Technology
Saif-Ur-Rehman Saif Abbasi

International Islamic University

\section{Resumen}

Esta investigación se centra en modelos específicos de salud y enfermedad, explorados por muchos investigadores en todo el mundo. El investigador resume las variaciones secuenciales y la crítica de cada modelo y se ha intentado integrar las orientaciones teóricas relevantes de la beta talasemia mayor. La beta talasemia mayor es un trastorno genético común, debido a anormalidades en la globina humana (alfa o beta). La mayor tasa de prevalencia de la enfermedad se ha visto en Arabia Saudita, Jordon, India, Bangladesh y Pakistán, debido a los repetidos matrimonios de primos, las fuertes creencias de las prácticas culturales y tradicionales y la falta de conocimiento para la prevención y el manejo de la beta talasemia mayor. El foco de los epidemiólogos se mantuvo en las causas genéticas e ignoró los factores sociales, culturales, religiosos y psicológicos que prevalecen sobre los aspectos biológicos de la salud. El académico y los expertos en salud carecían de un enfoque en las orientaciones teóricas de la beta talasemia mayor, este documento aclara los modelos de salud y enfermedad y proporciona un itinerario teórico lógico para la beta talasemia mayor.

Palabras clave: refugiados, beta talasemia mayor, sociología, salud, enfermedad, biopsicosocial 


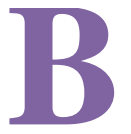

eta Thalassemia Major is a commonly known genetic disorder, which occurs due to the abnormality of beta-globin gene in human body and it transmits from parents to the children by biological means (Galanello \& Origa, 2010). The disease has become a public health problem across the world and especially in traditional and culturally oriented societies (Mufti et al., 2015), because of numerous social, cultural and religious practices such as; consanguinity (Khan et al., 2015), religious restrictions for the management and prevention of disease, lack of knowledge and access to the scientific health management tools (Ghafoor, 2016). It is also evident that due to this genetic disorder; parents, families and thalassemia patients have to face substantial amount of psychological and social estrangements e.g. social isolation, stigmatization, loneliness, weak social interaction, depression, anxiety and pessimism (Khurana et al., 2006).

The scholars and academicians have made enormous efforts to study the etiological and biological aspects of beta thalassemia major (Origa et al., 2005) but there are some theoretical gaps in the context of social, cultural and psychological explanations of the disease which have not been concealed due to lack of theoretical orientation of beta thalassemia major. The present study steered to incorporate the dominant models of health and illness to make a logical and theoretical context of beta thalassemia major in the field of health sociology. The models of health and illness have been reviewed by researchers and their basic explanations, criticisms and relevancies with beta thalassemia major have been tried to be summed up in this research paper.

\section{Beta Thalassemia Major; Evidences from Pakistan}

The number of beta thalassemia major's cases are growing day by day in Pakistan, approximately 5 to 9 thousand thalassemic children born every year (although the registered data is not available) (Hassan et al., 2019). The prevalence of this genetic disorder can be grasped across the world and especially in traditional and culturally dominated societies such as Pakistan, India, Bangladesh, Iran and Saudi Arabia (Hossain et al., 2020). The significant reasons for the higher prevalence of this genetic disorder are 
repeated cousin marriages (Khalid et al., 2019), lack of knowledge and awareness (of couples and families including general masses) regarding prevention of the disease (Naseem et al., 2008) and religious conformity (Arif et al., 2008), which do not allow people to adopt the scientific management practices. The studies conducted in the field of medical and social epistemology ignored the importance of such socio-cultural (knowledge, awareness, consanguinity and endogamy) and religious (false religious beliefs regarding marriage practices, abortion, prevention and management of the disease) aspects of the disease due to absence of conceptual and theoretical connotations, which can articulate these aspects.

\section{Study's Framework}

The present study is a qualitative systematic review of scholarly articles related to "Beta Thalassemia Major" "Sociology of Health and Illness" "Models of Health and Illness" and "Sociological Analysis of Health and Illness". The study aimed to incorporate the theoretical elucidation for beta thalassemia major and for this purpose we reviewed 187 research articles (published during 2000 to 2019). The selection of articles for analysis was initially based on the relevancy of title while, at the second stage the abstracts of selected articles were screened and finally the full articles were included or excluded. The study is based on systematic review of 50 articles, which were fully corroborated for detailed analysis (the statistical techniques or meta-analysis was not applied).

\section{Models of Health and Illness}

The numbers of health models are developed by sociologist, psychologist and health professionals to expose the cause and consequences of health and illness. These theorist and researchers intended to explain social (Hughes \& Paterson, 2006; Shakespeare \& Watson, 1997), cultural (Jegede, 2002; Wong \& King, 2007), psychological and ecological (Coreil, 2010; Murray \& Chamberlain, 1999; Willig, 2000), as well as biomedical explanations of health and illness (Farre \& Rapley, 2017). 
The prominent approaches in the field of health and illness gained a significance influence of biomedical and social vindications. Although these two approaches have significant differences with each other's, in terms of their examination, explanation and interpretation of disease and health. According to World Health Organization, health is defined as a state of being fit and well along with mental reasoning (WHO, 2005). In views of (Blaxter, 2004),

if a person can easily perform his/her daily activities e.g. performing household tasks and managing and participating in social gatherings, the state of robustness reveals he/she is healthy (p.122).

The most commonly found scientific and theoretical constructions of health are listed below.

\section{Biomedical Model of Health and Illness}

From most of the earlier explanations of health and illness, in the field of medical sociology biomedical model is instigator (Alonso, 2004). The model remained highly appreciated and followed by social and medical scientist during 1900s in Western Societies. In the view of biomedical model of health and illness, the complete functioning and malfunctioning of a body depends upon the biological explanations. The estimation of this model suggested that fixing biological issues by treating people through surgeries, using medicines and drugs for different therapies can ensure health and diminish illness (Minaire, 1992). Later on, with the emergence of different environmental, social and psychological explanations of health and illness, this model was criticized by many researchers (Adibi, 2014; Fertonani et al., 2015; Smart, 2006).

In many of the researchers' view, the absence of illness is defined as health (Calnan, 1987; Hughner \& Kleine, 2004; Williams, 1983), however many other lay perceptions have been seen by considering health as a relative phenomenon, that truly depends on the experiences and evaluations made by individuals and considered the state as health or not by means of their age, gender, social status and medical conditions. For those, who 
measured health on these lay perceptions, conceptualized health as only the absence of any physical problems which interfere their daily lives activities (Bury, 2005).

The explanation made by Baggott (2004) about the biomedical model depends on the physical functioning of an individual, if an individual is physically performing well he/she must be considered as healthy and the explanation of bad health can be described as the presence of any disease or illness, resulting physical malfunctioning due to any injury or infection. Biomedical model ignores the social and psychological factors and keep its focus on medical and biological changes which can be measured and defined in isolation. These biological and medical factors are failed to explain the complete state of health or illness because their elucidation depends on dysfunction of the organ or tissue of the body instated of overall condition of the patient (quality of life, wellbeing, adjustment and other social, psychological and mental aspects of health. The core of biomedical model entails a specific etiology e.g. every disease is/can be caused by the germs, bacteria or any kind of parasite (Seale, 2003).

An important illustration about biomedical model is based on its generic nature, which explains that each disease either viral, genetic or by any mean is based on the participles of universalism (Fischer, 2009). The approach ignores the cultural and social explanation and construction of health by believing in the biological agentic nature of health (Farmer et al., 2012). Denigration of this explanation is based on the idea of cultural variations to explain health and illness and the changing definition of any disease with the passage of time. Usually, it can be comprehended that what is seen as illness in any particular societies, at the given period of time, depends on social and cultural contextualization's (Naidoo \& Wills, 2016).

Another approach of biomedicine is supported by the spat of measurable biotic variables and perceived illness; as a deviation from normal range. The psychological abnormalities and impacts are the counter arguments for this explanation because of varying nature of mental and psychological factors of emotional and psychological disorders (Engel, 1978). It is also believed by health sociologists and psychologists that; mental abnormalities and emotional disorders often remain unclear and cannot be generalized on the principles of normality. Medical scientists have realized that human 
behaviors are not universal, and illness or health cannot be perceived universally (Cockerham \& Cockerham, 2014). It has also been realized by many researches of medical sciences, that human organism diverges in terms of structural and functional patterns and even the genetic variations remain unclear (Heylighen, 1999).

Having a strong belief on neutrality and objectivism, medical theories perceived individual as a product of biological progression. According to the biological naturalistic and objectivist; individual have little control over their lives and on the construction of health (Crawford, 2006). In the view of naturalistic and objective orientation of health and illness, as the biomedical model emphasizes, individuals remain unable to construct or contribute in the construction of health or illness (Crawford, 2006). The only explanation of health or illness remains on biological explanations, without considering the social, cultural and psychological causes. The critics have carped this argument of neutrality because there are various dictating forces in terms of social, cultural and political conducts which shape and effect the human health and illness. Being unhealthy could be the result of these (social, political/administrative and cultural) factors and practices (Harley et al., 2011; Williams, 1995).

In contemporary debates of biomedicine and biomedical, it has been acknowledged by health experts and researchers that there are multiple approaches for the interpretation of health and illness, instead of having a robust deem on biological determinism and value of neutrality (Müller, 2019). These multiple approaches include: social and psychological causes, anxiety, depression, cultural practices and different environmental factors (Noar et al., 2008). Current debates have incorporated the multidimensional approaches and their interrelatedness for the explanation and investigation of health and illness (Chenier, 1997). Biomedical model focuses on the quantification and treatment of any particular disease by means of only medications and clinical trials and due to this narrow and reductionist slant, it has been highly criticized by the social and environmental scientists because this approach perceives health as only the absence of any indisposition (Alberts et al., 2014; Engel, 1977). 


\section{Social Model of Health}

After the dominant criticism over the biomedical model in the $21_{\text {st }}$ Century, the literature drew attention of health experts and medical scientists to integrate social causes for the exoneration of health and illness. Social narratives were highlighted the cultural, religious, communal and familial practices, which shape the health of any individual and the practices to avoid ill health. The social conceptions included health and hygiene, marriages practices, psychological aspects and health disparities (Novotný et al., 2018), instead of only focusing on medicines and clinical experiments, which were dominant in earlier model (biomedical model). The social model included the social and cultural variations for the construction of health and explained health as a continuous process of individual, cultural and social practices (Fried et al., 2004). From Weberian explanation of life chances and choices (Cockerham et al., 1993) to sick role of (Parsons, 1951), health and illness have been conceptualized differently across the world (Larson, 1999) and the universal agreement on the definition of health is still debate (Zautra et al., 2010) because the social and cultural practices and understandings are not identical.

The social model interprets biological mechanisms in terms of social causes and constructs health or being unhealthy is based on social explanations. The model contextualizes health as an amalgamation of social factors including socio-economic status, cultural practices, sanitation and hygiene. The proponents of the social model (Anastasiou \& Kauffman, 2011; Ghaemi, 2009) have accentuated to include social aspects e.g. poverty, awareness, parental practices, ethnic and cultural practices and religious beliefs to be cuddled for the understanding of health and illness. Social model also allowed mental and psychological factors to be given share in its core domain because these (mental and psychological) aspects either become causes or consequences of any disease (Kawachi \& Berkman, 2001).

\section{Bio-psychosocial Model}

Another major theoretical and practical contribution by many researchers (Engel, 1978, 1981, 1982) in sociology of health and illness is the bio- 
psychosocial model of health and illness. Bio-psychosocial model is known as the extension of the former model (biomedical). This model is also known as a multi-factorial approach of health and illness because it includes biological, psychological and social aspects, implicated with a patient's health status (Alonso, 2004; Havelka et al., 2009). This multidimensional approach of health and illness is characterized based on:

1. biological factors (genes and chromosomes)

2. behavioral/psychological factors (life styles, stress management practices, health believes etc.)

3. social factors (cultural, religious life histories, social relations and social support etc.).

It includes social, psychological and biological factors that influence health, unlike biomedical model that only theorizes and measures health, illness and practices based on genetic and biological aspects.

\section{Web of Causation}

The major contribution by epidemiologist was to develop the web of causation approach also known as agent host model, which is an epidemiological model of health and illness and views the disease as a result of an intricate set-up of interviewing risk factors between the agents, the host and the environment (Norell, 1984). This model includes the elements of environment such as unhygienic living conditions, pollution, problems of sanitations, contaminated water and food and industrial chemicals which are responsible for spreading the virus of any disease and due to the carless practices and unhygienic living environment, the inhabitant of polluted environment become vulnerable towards unhealth life style. and the individual become recipient for being careless or unaware of health standards (MacMahon et al., 1960). The model emphasizes on healthy environment and precautionary individual's practices by protecting and cleaning their own surroundings. The ideal health standards can be ensuring by avoiding the unhealthy practices, protecting environment and ensuring the standardized practices of quality of life by the individual. 


\section{Ecological model}

The ecological model is derived from the broad field of human ecology, which studies the interrelationship of human interaction, social organization, and the natural environment. It relates the quality of life to the development of ecological resources at a population level, in terms of addressing the environmental impact of urban and rural settlements, industry, technology, and culture. Ecological model of health has a similarity with agent host model, because both include the environment as an element to ensure health state of any individual (Reifsnider et.al., 2005; Salliset al., 2015).

\section{New public health}

The contemporary approach in the field of sociology of health and illness is the emergence of new public health approach (Baum, 1998). This model of health that links the traditional public health concerns of sanitation, hygienic practices, clean air and water with the social, cultural, behavioral and political-economic factors that affect people's health. It directs attention to the prevention of illness trough community participation and social reforms that address living and working conditions. Instead of merely focusing on individual factors, the new public health model indicates a broader range of social, political, historical and economic forces of health's production and distribution (Frenk, 1993). The model focuses on policies and behaviors which changes the health practices of communities (Fielding et al., 2010).

\section{The Limits of Medicine}

Although biomedical model of health and illness significantly contributed in the field of health and illness especially the treatment, causes and prevention of diseases. Whereas, a very significant criticism can be found on biomedical model with reference to the point of view of social and psychological researchers and philosophers. They pointed out that biomedical model ignored social, behavioral and psychological parameters and aspects of health and illness. Neglecting these factors, an individual cannot understand the complexities of health and illness. One of the major 
criticisms on bio-medical, pointed out that, the causation of disease does not always mean the interaction (Dubos, 1987). The prevalence of disease is based on multiple factors, that can be physical, psychological (stress) and related to practices (food and nutrition). Another major criticism on biomedical model is reductionism (Mehta, 2011).

In the view of many researchers (Daniels, 1989; Gifford, 2016), biomedical model focuses on smaller units (e.g. cells, biological organism) and completely ignores the general and holistic aspects such as social and psychological. Reductionism also lead to biological determinism and according to this point of view, determinism and explanation of health and illness is based on the biologically determined factors (chromosomes, hormones and genes), while many aspects of life, such as happiness, psychological and emotional disorders, anxiety, depression and even many genetic disorders are based on social and cultural practices rather than solely depending on biological factors (Germov, 2014).

In sum, biomedical model is highlighted by its nature of victim blaming. As it creates culpability for any sick individual among other members of his/her community by considering the individual a sole cause of his/her disease and ignore all other social facets by which a disease can prevail. Because of many social, economic, religious and cultural practices, attitudes and believes, biomedical model face a very strong criticism by social researchers (Broom \& Adams, 2016; Geist \& Dreyer, 1993; Lyman, 1989). Due to the widespread criticism on biomedical model of health and illness, medical and social researchers developed varieties of new models and frameworks to explain and contextualize health and illness. The significant models in the field of health and illness other than biomedical interpretations include; social model, bio-psychosocial model, web of causation, ecological and new public health model of health and illness. These models significantly highlighted the environmental, social, ecological, cultural and psychological aspects of health and construction of health and illness.

\section{Social Construction of Health and Illness}

Sociology of health and illness seeks to examine the effect of social aspects such as caste, class, ethnicities, marriage patterns, socio-economic status, 
family systems and socio-political conditions on health of any society (Sharf \& Vanderford, 2003). In the discussion of health sociology, sociologists have tried to incorporate the aspects of social pathologies, health seeking behaviours, individual and collective communal practices, to understand any disease (Conrad \& Barker, 2010).

In the view of (Fleming \& Parker, 2015), health or absence of health is not merely the attribute of biological or natural aspects (p. 27), social researches found the contribution of socio-economic status, cultural believes and practices (consanguinity, stigmatization and marriage patterns) and the values (cast system, ethnic preferences etc.) which have a greater influence over the assertion of being healthy or not. In the diverse definitions of Sociology of health (Mattlin, 2018) focused on three major domains in the field of health and illness: the first one is the conceptualization of health, second is the study of measurement and social distribution of health and third is known as the justification of the patterns in health and illness. Furthermore, there is a significant difference between medical sociology (that focuses on epidemiological demeanors, health institutions and dexterities of medical practitioners) and sociology of health and illness (Nettleton, 2006) because sociology of health and illness includes social, cultural, economic and political facets, which influence the health practices, statuses and focus on underlying causes of any disease $(p, 13)$.

Sociology of health and illness swathes the ecological and environmental causes of an illness and attitudes and perceptions on individuals towards the understanding and precautions of any disease. It also focuses on psychological and emotional problems, allied with the jounce of any mental or psychological malady. Unlike studying or researching the specific extent of any disease, sociology of health and illness have a holistic view to study the collective effects and cardinal geneses (social, psychological, cultural, political and emotional) of any scrupulous disease (McKee, 1988). Conceptualization of health and illness varies from the point of view of different schools, the conventional approaches to health and illness focus on biological and behavioural explanations and construction of health and illness (Arber, 1987). However the formation of health and illness is based on many social factors, e.g. class differences, awareness, knowledge, attitudes, perceptions, practices, socio-economic status, gender, race and 
ethnicity (Merrild et al., 2016). Because of all these social aspects, researchers focused to find out the social causes and consequences of many chronic disease and genetic disorders. The individualistic approaches tend to focus on and alter the life styles and practices, which are prone to the propagation of many genetic disorders i.e. thalassemia.

\section{Theoretical Construction of Beta Thalassemia Major}

As identified by (Goffman, 1963), a person becomes stigmatized based on an attribute, that negatively effects his/her social interaction with rest of the community or society (p. 138). In the view of (Goffman, 1986), stigma is classified into three major forms. A first factor is any kind of physical disability of body image while the second explanation of stigma is, any kind of individual characteristic (e.g. mental and psychological abnormality) and lastly, he proposed that tribal factors such as race, gender, cast, religion and ethnicity also endorse stigma.

It has been explored by many researchers (Anum \& Dasti, 2016) that patients and families of thalassemia are usually pilloried, particularly because of tribal factors. Mostly these individuals (patients of thalassemia disease) are called and pronounced as thalassemic (being labeled based on their disease). Social isolation and exclusion from communal activities are hard facts, often faced by the parents and families of sick children due to their disease. In many cases, mothers suffer severe mental and psychological stress and face social pressure due to the illness of their child (Arbabisarjou et al., 2015).

In Pakistan, where the patriarchal family structure is excursed overpoweringly, and women must face a strong level of criticism and stigmatization for giving birth to a child with any genetic disorder like thalassemia. The ideas of victim blaming and self-blaming (Shiloh, 2006) become germane in the context of thalassemia because parents of thalassemic children indict themselves for being the cause of thalassemia (Murphy, 2005).

The application of bio-psychosocial model in thalassemia can interpret the biological factors related to the thalassemia in the context of genetic vulnerability, disability and physical health while social factors includes 
awareness and knowledge about the disease and cultural practices for the understanding and propagation of thalassemia. Reviewing the literature showed that psychological aspects are only measured as impact of thalassemia on patients and their families (Baraz et al., 2016; Behdani et al., 2015; Mansoor et al., 2018), however genetic abnormalities (Brancaleoni et al., 2016; de Dreuzy et al., 2016) and socio-cultural factors (Sarvestani et al., 2019; Seyedifar et al., 2016) are the major risk factors of thalassemia propagation.

\section{Sociological Analysis of Beta Thalassemia Major}

Over the period, medical sociology morphed into the specific discipline known as sociology of health and illness and social scientists considered medicines too restrictive as an indicator of the sociological interest in health realm (Bloom et al., 2002; Conrad, 2008). A shift in the field of medicines and then into medical sociology can be seen by the critics on epidemiologist and medical sociologist who were researching and analyzing health and illness on solely clinical parameters. Ignoring social, psychological and cultural factors allied with health and illness caused seriousness in failure of finding the risk factors and basis of many chronic genetic disorders, including thalassemia. The remarkable efforts of social scientists in determining the social factors as underpinning with health and illness develop independent discipline-Sociology of Health and Illness.

Perceiving health and illness with perspective of sociology became more distinctive after the contribution of American Sociologist Charles Wright Mills (1916-62), who used a very idiosyncratic term "Sociological Imagination" to describe any social aspect of human life with the lens of sociology. This method provides an in-depth and a very comprehensive understanding of social life. The perspective enables us to understand social problems, their possible causes and proposed solution to avoid future incongruities. Whereas thalassemia as a major public health problem across the globe and particularly in Pakistan, required social understanding, remedies and solution rather than focusing on biomedical, because it has more to deal with social aspects of life. 
The Australian sociologist Evan Willis suggests that the sociological imagination consists of four interrelated parts. The intension, to apply these aspects to gain understanding of thalassemia as a public health problem, existing across the world can be traced and explored with the lens of sociology (Willis, 1993).

1. Historical factors: How the past influences the present (family history of the patients and inheritance leads to the higher propagation of thalassemia)

2. Cultural factors: How culture impacts on our lives (consanguinity, religiousity, stigmatization and termination of pregnancy)

3. Structural factors: How particular forms of social organization affect our lives (treatment cost, hospital expenditures, blood transfusion)

4. Critical factors: How we can improve our social environment (awareness level of the respondents about prenatal and post marriage screening, knowledge about the disease and its preventive measures can reduce the prevailing condition of thalassemia across the world and especially in Pakistan)

\section{Conclusion}

Beta thalassemia major is a prevailing public health problem across the world and especially in developing countries. The prominent social factors (lack of knowledge and awareness about prevention and management of the disease, denial of pre/postnatal screening practices and genetic counselling), cultural factors (consanguinities, ethnic preferences for marriage, blind religious beliefs and role of patriarchy) propagates this genetic ailment. The disease pretense a strong psychological and social impact on the families, parents and sick children. The biological explanations (abnormalities in hemoglobin) are prime causes but the generic nature of social, cultural and religious aspects also required an academic deportment to be incorporated, while researching beta thalassemia major. Due to lack of theoretical orientations, researchers left leaved gray areas for suggesting theoretical construction of beta thalassemia major. With this aim, the present study includes bio-psychosocial model as a theoretical framework to identify the 
social, cultural, economic and disease allied risk factors of beta thalassemia major, while the psychological factors are considered as an impact on patients and their families because these factors do not prompt thalassemia, yet impose a significant effect on quality of life, social adjustment and wellbeing of parents and patients. It is also evident that even though the social and psychological narrations have been widely accepted by the researches and experts but still there is a debate and a negative argument prevails against these psychosocial explanations of health and illness.

\section{References}

Adibi, H. (2014). Health: Its Implications within the Biomedical and Social Models of Health-a Critical Review. Cyber Journals: Multidisciplinary Journals of Science and Technology, 4(2), 16-23. Alberts, B., Kirschner, M. W., Tilghman, S., \& Varmus, H. (2014). Rescuing US biomedical research from its systemic flaws. Proceedings of the National Academy of Sciences, 111(16), 57735777. http://doi.org/10.1073/pnas.1404402111

Alonso, Y. (2004). The biopsychosocial model in medical research: the evolution of the health concept over the last two decades. Patient Education and Counseling, 53(2), 239-244. http://doi.org/10.1016/S0738-3991(03)00146-0

Anastasiou, D., \& Kauffman, J. M. (2011). A social constructionist approach to disability: Implications for special education. Exceptional Children, 77(3), 367-384. http://doi.org/10.1177/001440291107700307

Anum, J., \& Dasti, R. (2016). Caregiver burden, spirituality, and psychological well-being of parents having children with thalassemia. Journal of Religion and Health, 55(3), 941-955. http://doi.org/10.1007/s10943-015-0127-1

Arbabisarjou, A., Karimzaei, T., \& Jamalzaei, A. (2015). The perception of Biological experience in patients with major thalassemia: A qualitative research. Global Journal of Health Science, 7(1), 79. http://doi.org/10.5539/gjhs.v7n1p79 
Arber, S. (1987). Social class, non-employment, and chronic illness: continuing the inequalities in health debate. British Medical Journal (Clinical Research ed.), 294(6579), 1069-1073. http://doi.org/10.1136/bmj.294.6579.1069

Arif, F., Fayyaz, J., \& Hamid, A. (2008). Awareness among parents of children with thalassemia major. The Journal of the Pakistan Medical Association, 58(11), 621-624.

Baraz, S., Miladinia, M., \& Mosavinouri, E. (2016). A comparison of quality of life between adolescences with beta thalassemia major and their healthy peers. International Journal of Pediatrics, 4(1), 1195-1204. http://doi.org/10.22038/IJP.2016.6228

Baum, F. (1998). The new public health: an Australian perspective. Oxford University Press.

Behdani, F., Badiee, Z., Hebrani, P., Moharreri, F., Badiee, A. H., Hajivosugh, N., Rostami, Z., Akhavanrezayat, A. (2015). Psychological aspects in children and adolescents with major thalassemia: A case-control study. Iranian Journal of Pediatrics, 25(3). http://doi.org/10.5812/ijp.25(3)2015.322

Blaxter, M. (2004). Health. Cambridge Polity Press.

Bloom, J. R., Hu, T. w., Wallace, N., Cuffel, B., Hausman, J. W., Sheu, M. L., \& Scheffler, R. (2002). Mental health costs and access under alternative capitation systems in Colorado. Health Services Research, 37(2), 315-340. http://doi.org/10.1111/1475-6773.025

Brancaleoni, V., Di Pierro, E., Motta, I., \& Cappellini, M. (2016). Laboratory diagnosis of thalassemia. International Journal of Laboratory Hematology, 38, 32-40. http://doi.org/10.1111/ijlh.12527

Broom, A., \& Adams, J. (2016). A critical social science of evidence-based healthcare. In A. Broom \& J. Adams (Eds.), Evidence-based healthcare in context. Critical social sciences perspective (pp. 15-34). Routledge.

Bury, M. (2005). Postmodernity and health. In G. Scambler \& P. Higgs (Eds.), Modernity, medicine and health. Medical Sociology towards 2000 (pp. 19-46). Routledge.

Calnan, M. (1987). Health and illness. The lay perspecctive. Tavistock Publications. 
Chenier, M. C. (1997). Review and analysis of caregiver burden and nursing home placement: the multiple problems and variables affecting the caregiving relationships require multiple approaches and interventions. Geriatric Nursing, 18(3), 121-126. http://doi.org/10.1016/s0197-4572(97)90029-X

Cockerham, W. C., Abel, T., \& Lüschen, G. (1993). Max Weber, formal rationality, and health lifestyles. Sociological Quarterly, 34(3), 413425. http://doi.org/10.1111/j.1533-8525.1993.tb00119.x

Cockerham, W. C., \& Cockerham, G. B. (2014). Health and globalization. The Wiley Blackwell Encyclopedia of Health, Illness, Behavior, and Society, 954-972.

Conrad, P. (2008). The sociology of health and illness. Worth Publishers.

Conrad, P., \& Barker, K. K. (2010). The social construction of illness: Key insights and policy implications. Journal of Health and Social Behavior, 51(1_suppl), S67-S79. http://doi.org/10.1177/0022146510383495

Coreil, J. (2010). Social and behavioral foundations of public health. Sage.

Crawford, R. (2006). Health as a meaningful social practice. Health: An Interdisciiplinary Journal for the Study of Health, Illness, and Medicine, 10(4), 401-420. http://doi.org/10.1177/1363459306067310

Daniels, N. (1989). The biomedical model and just health care: Reply to Jecker. The Journal of Medicine and Philosophy, 14(6), 677-680. http://doi.org/10.1093/jmp/14.6.677

de Dreuzy, E., Bhukhai, K., Leboulch, P., \& Payen, E. (2016). Current and future alternative therapies for beta-thalassemia major. Biomedical Journal, 39(1), 24-38. http://doi.org/10.1016/j.bj.2015.10.001

Dubos, R. J. (1987). Mirage of health: utopias, progress and biological change. Rutgers University Press.

Engel, G. L. (1977). The need for a new medical model: a challenge for biomedicine.

Science, 196(4286),

129-136. http://doi.org/10.1126/science.847460

Engel, G. L. (1978). The biopsychosocial model and the education of health professionals. Annals of the New York Academy of Sciences, 310(1), 169-181. http://doi.org/10.1111/j.1749-6632.1978.tb22070.x 
Engel, G. L. (1981). The clinical application of the biopsychosocial model. The Journal of Medicine and Philosophy: A Forum for Bioethics and Philosophy of Medicine.

Engel, G. L. (1982). The biopsychosocial model and medical education: who are to be the teachers? The New England Journal of Medicine, 306, 802-805. http://doi.org/10.1056/NEJM198204013061311

Farmer, J., Bourke, L., Taylor, J., Marley, J. V., Reid, J., Bracksley, S., \& Johnson, N. (2012). Culture and rural health. Australian Journal of Rural Health, 20(5), 243-247. http://doi.org/10.1111/j.14401584.2012.01304.x

Farre, A., \& Rapley, T. (2017). The New Old (and Old New) Medical Model: Four Decades Navigating the Biomedical and Psychosocial Understandings of Health and Illness. Healthcare (Basel, Switzerland), 5(4), 88. https://doi.org/10.3390/healthcare5040088

Fertonani, H. P., de Pires, D. E. P., Biff, D., \& dos Anjos Scherer, M. D. (2015). The health care model: concepts and challenges for primary health care in Brazil. Ciencia \& Saude Coletiva, 20(6), 1869-1878. http://doi.org/10.1590/1413-81232015206.13272014

Fielding, J. E., Teutsch, S., \& Breslow, L. (2010). A framework for public health in the United States. Public Health Reviews, 32(1), 174. http://doi.org/10.1007/BF03391597

Fischer, M. M. (2009). Anthropological futures. Duke University Press.

Fleming, M. L., \& Parker, E. (2015). Introduction to Public Health eBook. Elsevier Health Sciences.

Frenk, J. (1993). The new public health. Annual Review of Public Health, 14(1), 469-490. http://doi.org/10.1146/annurev.pu.14.050193.002345

Fried, L. P., Carlson, M. C., Freedman, M., Frick, K. D., Glass, T. A., Hill, J., McGill, S., Rebok, G. W., Seeman, T., Tielsch, J., Wasik, B. A., \& Zeger, S. (2004). A social model for health promotion for an aging population: initial evidence on the Experience Corps model. Journal of Urban Health, 81(1), 64-78. http://doi.org/10.1093/jurban/jth094

Galanello, R., \& Origa, R. (2010). Beta-thalassemia. Orphanet Journal of Rare Diseases, 5(1), 11. http://doi.org/10.1186/1750-1172-5-11

Geist, P., \& Dreyer, J. (1993). The demise of dialogue: A critique of medical encounter ideology. http://doi.org/10.1080/10570319309374446 
Germov, J. (2014). Second opinion: an introduction to health sociology. Oxford University Press.

Ghaemi, S. N. (2009). The rise and fall of the biopsychosocial model. The British Journal of Psychiatry, 195(1), 3-4. http://doi.org/10.1192/bjp.bp.109.063859

Ghafoor, M. B. (2016). Level of awareness about thalassemia among parents of thalassaemic children. Journal of Rawalpindi Medical College, 20(3), 209-211.

Gifford, F. (2016). The Biomedical Model and the Biopsychosocial Model in Medicine. In M. Solomon, J. R. Simon \& H. Kincaid (Eds.), The Routledge Companion to Philosophy of Medicine (pp. 459-468). Routledge.

Goffman, E. (1963). Stigma. Notes on the Management of Spoiled Identity. Penguin.

Goffman, E. (1986). Stigma: notes on the management of spoiled identity. Touchstone.

Harley, K., Willis, K., Gabe, J., Short, S. D., Collyer, F., Natalier, K., \& Calnan, M. (2011). Constructing health consumers: Private health insurance discourses in Australia and the United Kingdom. Health Sociology Review, 20(3), 306-320. http://doi.org/10.5172/hesr.2011.20.3.306

Hassan, J., Nadeem, M., Ansari, S. H., Ahmed, S., Parveen, S., \& Shamsi, T. (2019). Frequency of Alpha Thalassaemia in homozygous Beta Thalassaemia paediatric patients and its clinical impact at a blood disease centre in Karachi, Pakistan. JPMA, 69(959).

Havelka, M., Despot Lučanin, J., \& Lučanin, D. (2009). Biopsychosocial model-the integrated approach to health and disease. Collegium Antropologicum, 33(1), 303-310.

Heylighen, F. (1999). The growth of structural and functional complexity during evolution. In F. Heylighen, J. Bollen \& A. Riegler (Eds.), The evolution of complexity (pp. 17-44). Kluwer Academic.

Hossain, M. S., Hasan, M. M., Raheem, E., Islam, M. S., Al Mosabbir, A., Petrou, M., \& Siddiqee, M. H. (2020). Lack of knowledge and misperceptions about thalassaemia among college students in 
Bangladesh: a cross-sectional baseline study. Orphanet Journal of Rare Diseases, 15(1), 1-10. http://doi.org/10.1186/s13023-020-1323-y Hughes, B., \& Paterson, K. (2006). The social model of disability and the disappearing body: Towards a sociology of impairment. In L. Barton (Ed.), Overcoming disabling barriers. 18 years of disability and society (pp. 101-117). Routledge.

Hughner, R. S., \& Kleine, S. S. (2004). Views of health in the lay sector: A compilation and review of how individuals think about health. Health: An Interdisciiplinary Journal for the Study of Health, Illness, and Medicine, 8(4), 395-422. http://doi.org/10.1177/1363459304045696

Jegede, A. S. (2002). The Yoruba cultural construction of health and illness. Nordic Journal of African Studies, 11(3), 14-14.

Kawachi, I., \& Berkman, L. F. (2001). Social ties and mental health. Journal of Urban Health, 78(3), 458-467. http://doi.org/10.1093/jurban/78.3.458

Khan, M. S., Ahmed, M., Khan, R. A., Mushtaq, N., \& Shah, M. W. U. (2015). Consanguinity ratio in b-thalassemia major patients in District Bannu. The Journal of the Pakistan Medical Association, 65(11), 1161-1163.

Khalid, N., Noreen, K., Qureshi, F. M., \& Mahesar, M. (2019). Knowledge of thalassemia and consanguinity: A multicenter hospital based retrospective cohort study from metropolitan city of Karachi, Pakistan. The Professional Medical Journal, 26(09), 1580-1586. http://doi.org/10.29309/TPMJ/2019.26.09.168

Khurana, A., Katyal, S., \& Marwaha, R. K. (2006). Psychosocial burden in thalassemia. The Indian Journal of Pediatrics, 73(10), 877-880. http://doi.org/10.1007/BF02859278

Larson, J. S. (1999). The conceptualization of health. Medical Care Research and Review, 56(2), 123-136. http://doi.org/10.1177/107755879905600201

Lyman, K. A. (1989). Bringing the social back in: A critique of the biomedicalization of dementia. The Gerontologist, 29(5), 597-605. http://doi.org/10.1093/geront/29.5.597

MacMahon, B., Pugh, T. F., \& Ipsen, J. (1960). Epidemiologie Methods. J \& A. Churchill Ltd. 
Mansoor, S., Othman, Z., Othman, A., \& Husain, M. (2018). A Descriptive Study on Quality of Life among Adolescents with Beta-Thalassemia Major in the Maldives. International Medical Journal, 25(4), 211214. http://doi.org/10.5281/zenodo.2588035

Mattlin, M. (2018). Examining the Social Construction of Health, Illness, and Wellness in Anti-science Communities. Non published thesis, defended at Vanderbilt University.

McKee, J. (1988). Holistic health and the critique of Western medicine. Social Science \& Medicine, 26(8), 775-784. http://doi.org/10.1016/0277-9536(88)90171-2

Mehta, N. (2011). Mind-body dualism: A critique from a health perspective. Mens Sana Monographs, 9(1), 202. http://doi.org/10.4103/09731229.77436

Merrild, C. H., Vedsted, P., \& Andersen, R. S. (2016). Situating Social Differences in Health and Illness Practices. Perspectives in Biology and Medicine, 59(4), 547-561. http://doi.org/10.1353/pbm.2016.0047

Minaire, P. (1992). Disease, illness and health: theoretical models of the disablement process. Bulletin of the World Health Organization, $70(3), 373$.

Müller, R. (2019). A task that remains before us: Reconsidering inheritance as a biosocial phenomenon. Seminars in Cell \& Developmental Biology.

Murphy, R. (2005). Health professionals and ethnic Pakistanis in Britain: risk, thalassaemia and audit culture. Thesis defended at University of St Andrews.

Murray, M., \& Chamberlain, K. (1999). Qualitative health psychology: Theories and methods. Sage.

Naidoo, J., \& Wills, J. (2016). Foundations for Health Promotion-E-Book. Elsevier Health Sciences.

Naseem, S., Ahmed, S., \& Vahidy, F. (2008). Impediments to prenatal diagnosis for beta thalassaemia: experiences from Pakistan. Prenatal Diagnosis, 28(12), 1116-1118. http://doi.org/10.1002/pd.2133

Nettleton, S. (2006). The sociology of health and illness. Cambridge Polity Press. 
Noar, S. M., Chabot, M., \& Zimmerman, R. S. (2008). Applying health behavior theory to multiple behavior change: considerations and approaches. Preventive Medicine, 46(3), 275-280. http://doi.org/10.1016/j.ypmed.2007.08.001

Norell, S. (1984). Models of causation in epidemiology. In L. Nordenfelt, B. Ingemar \& B. Lindahl (Eds.), Health, Disease, and Causal Explanations in Medicine (pp. 129-135). Springer.

Novotný, J., Ficek, F., Hill, J. K., \& Kumar, A. (2018). Social determinants of environmental health: a case of sanitation in rural Jharkhand. Science of The Total Environment, 643, 762-774. http://doi.org/10.1016/j.scitotenv.2018.06.239

Mufti, G. E. R., Towell, T., \& Cartwright, T. (2015). Pakistani children's experiences of growing up with beta-thalassemia major. Qualitative Health Research, 25(3), 386-396. http://doi.org/10.1177/1049732314552663

Origa, R., Fiumana, E., Gamberini, M. R., Armari, S., Mottes, M., Sangalli, A., \& Borgna-Pignatti, C. (2005). Osteoporosis in $\beta$-thalassemia: clinical and genetic aspects. Annals of the New York Academy of Sciences, 1054(1), 451-456. http://doi.org/10.1196/annals.1345.051

Parsons, T. (1951). Illness and the role of the physician: A sociological perspective. American Journal of Orthopsychiatry, 21(3), 452-460. http://doi.org/10.1111/j.1939-0025.1951.tb00003.x

Reifsnider, E., Gallagher, M., \& Forgione, B. (2005). Using ecological models in research on health disparities. Journal of Professional Nursing, 21(4), 216-222. http://doi.org/10.1016/j.profnurs.2005.05.006

Sallis, J. F., Owen, N., \& Fisher, E. (2015). Ecological models of health behavior. In K. Glanz, B. K. Rimer \& K. Viswanath (Eds.), Health Behavior: Theory, Research, and Practice (pp. 43-64). San Francisco: Jossey-Bass.

Sarvestani, K. A., Hasanifar, A., \& Bagheri, R. (2019). Some Determinants of Contraceptive Use Among Women of Reproductive Age Who Have Children with Thalassemia Major in Sistan and Baluchestan Province, Iran. Women Health Bulletin, 6(2), e90092. http://doi.org/10.5812/whb.90092 
Seale, C. (2003). Health and media: an overview. Sociology of health \& illness, 25(6), 513-531. http://doi.org/10.1111/1467-9566.t01-1-00356 Seyedifar, M., Dorkoosh, F. A., Hamidieh, A. A., Naderi, M., Karami, H., Karimi, M., Fadaiyraryeny, M., Musavi, M., Ahmadian-Attari, M. M., Hadjibabaie, M., Cheraghli, A. M., \& Akbari, S. A. (2016). Healthrelated quality of life and health utility values in beta thalassemia major patients receiving different types of iron chelators in Iran. International Journal of Hematology-Oncology and Stem Cell Research, 10(4), 224-231.

Shakespeare, T., \& Watson, N. (1997). Defending the social model.

Disability \& Society, 293-300. http://doi.org/10.1080/09687599727380

Sharf, B. F., \& Vanderford, M. L. (2003). Illness narratives and the social construction of health. In T. L. Thompson, R. Parrott \& J. F. Nussbaum (Eds.), The Routledge handbook of health communication (pp. 23-48). Routledge.

Smart, J. (2006). Challenges to the biomedical model of disability. Advances in Medical Psychotherapy \& Psychodiagnosis, 12, 1-4.

World Health Organization (2005). Global tuberculosis control: surveillance, planning, financing-WHO report 2005. World Health Organization.

Williams, R. (1983). Concepts of health: an analysis of lay logic. Sociology, 17(2), 185-205. http://doi.org/10.1177/0038038583017002003

Williams, S. J. (1995). Theorising class, health and lifestyles: can Bourdieu help us? Sociology of Health \& Illness, 17(5), 577-604. http://doi.org/10.1111/1467-9566.ep10932093

Willig, C. (2000). A discourse-dynamic approach to the study of subjectivity in health psychology. Theory \& Psychology, 10(4), 547-570. http://doi.org/10.1177/0959354300104006

Willis, E. (1993). The historical sociology of healthcare Health Research in Practice (pp. 97-111): Springer. https://doi.org/10.1007/978-1-48994497-9_7

Wong, N., \& King, T. (2007). The cultural construction of risk understandings through illness narratives. Journal of Consumer Research, 34(5), 579-594. http://doi.org/10.1086/520078 
Zautra, A. J., Hall, J. S., \& Murray, K. E. (2010). A new definition of health for people and communities. Handbook of adult resilience, 1 .

Muhammad Abo ul Hassan Rashid is faculty member of Shaheed

Zulfikar Ali Bhutto Institute of Science and Technology and PhD scholar at the International Islamic University, Pakistan.

Saif-Ur-Rehman Saif Abbasi, is Professor of Sociology at the International Islamic University, Pakistan.

Email: hassan.rashid@szabist-isb.edu.pk 